\title{
MULTIVARIATE ANALYSIS ON CRANIUM MEASUREMENTS OF THREE BREEDS OF GOAT IN CENTRAL JAVA
}

\author{
H. F. Suryani, E. Purbowati and E. Kurnianto \\ Faculty of Animal and Agricultural Sciences, Diponegoro University, \\ Tembalang Campus, Semarang 50275 \\ Corresponding E-mail: hasnafajar@gmail.com
}

Received September 15, 2013; Accepted November 04, 2013

\begin{abstract}
ABSTRAK
Tujuan penelitian ini adalah untuk 1) mengidentifikasi ukuran dan bentuk kranium dari tiga bangsa kambing lokal Jawa Tengah (Kejobong, Kacang dan Peranakan Ettawa), 2) mengetahui efektivitas pengukuran kranium dengan menggunakan analisis multivariat dan 3) memperkirakan jarak genetik antara tiga bangsa kambing. Materi yang digunakan adalah kranium kambing Kejobong, Kacang dan Peranakan Ettawa (PE), jenis kelamin betina yang berumur sekitar 4 tahun (berdasarkan susunan gigi seri) dengan masing-masing kranium sebanyak 30, 10 dan 10 buah. Data yang diambil sebanyak 27 ukuran kranium, dianalisis dengan analisis multivariat yang meliputi GLM, CANDISC, PRINCOMP dan DISCRIM. Analisis yang digunakan untuk menggambarkan jarak genetik antar bangsa adalah UPGMA dari MEGA 5. Hasil penelitian menunjukkan bahwa kambing PE cenderung menunjukkan ukuran terbesar, diikuti oleh kambing Kejobong dan kambing Kacang. Kranium kambing Kejobong memiliki ukuran kecil dengan bentuk yang besar. Hal berbeda terjadi pada kambing Kacang yang menunjukkan ukuran dan bentuk kranium yang relatif kecil. Kranium kambing Kacang menunjukkan ukuran yang lebih kecil (Komponen Utama I atau KU-I = -2) dibandingkan dengan kambing PE (KU-I = 3) dan Kejobong (KU-I = -1). Analisis untuk mengklasifikasikan ketiga bangsa kambing lokal tersebut menunjukkan keakuratan yang sangat tinggi (100\%), ditunjukkan dengan tidak adanya kesalahan (0\%). Hubungan jarak genetik kambing Kejobong lebih dekat dengan kambing Kacang, dibandingkan dengan kambing PE.
\end{abstract}

Kata kunci: kraniometri, kambing Kejobong, kambing Kacang, kambing PE

\section{ABSTRACT}

The purposes of this study were to 1) identify the size and shape of cranium of three breeds of Central Java local goats (Kejobong, Kacang and Ettawa Grade), 2) examine the effectiveness of multivariate analysis of cranial measurement and 3) estimate genetic distance among three local breeds of goat. The material used was cranium from female Kejobong, Kacang and Ettawa Grade goats, aged for about 4 years (determined on the basis based on eruption of teeth), the number of specimens were 30; 10 and 10, respectively. Twenty seven cranial measurements used to data observed, multivariate analysis of GLM, CANDISC, PRINCOMP and DISCRIM were used to analysis all data observed. UPGMA of MEGA 5 was used to illustrate the distance among breeds. Results showed that Ettawa Grade tended to show the largest size, followed by Kejobong and Kacang goats. Kejobong goat showed small cranium size with large cranium shape. Different things was found in Kacang goats in which cranium size and cranium shape are relatively small. Kacang breed showed the smaller size (Principal Component I or PC-1 = -2) compared to Ettawa Grade (PC-I = 3) and Kejobong goat (PC-I = -1). Analysis for classifying three breeds of local goat resulted in high accuracy $(100 \%)$ as indicated by $0 \%$ of erroneous level $(0 \%)$. Kejobong goat was close to in the genetic relationship to Kacang goat compared to Ettawa Grade goat.

Keywords: craniometry, Kejobong goat, Kacang goat, Ettawa Grade goat 


\section{INTRODUCTION}

Goats are the potential animals to be developed in Indonesia. Goats have many advantages such as easy maintenance, and prolific that can give birth to twins and can give birth three times in two years. Moreover, goat market prospects are also very promising. Once goats have short reproduction cycle and produce quality meat, they are raised as an extra investment without major labor input by the marginal farmers (Sodiq and Sumaryadi, 2002).

Central Java have the highest goat population in Indonesia. According to the Direktorat Jenderal Peternakan dan Kesehatan Hewan (2013), goat population in 2012 in Central Java were $3,889,878$ heads. In Central Java province, there are four local breeds of goats, namely Kacang, Jawarandu, Ettawa Grade and Kejobong goats (Kurnianto et al., 2013). In developing local goats, it needs to study about the potential of phenotypically to see the diversity of goats. Kacang is an indigenous breed of goat found in Indonesia. Ettawa Grade goats are descended originally from crossing between Kacang and Ettawa goats (Sodiq and Haryanto, 2007). Study about Kejobong goat is lack. Kejobong goat population is mostly centralized in Kejobong Sub-district, Purbalingga Regency, Central Java (Purbowati and Rianto, 2010). The number of Kejobong goats in Purbalingga was about 43,708 heads (Dinas Peternakan dan Perikanan Kabupaten Purbalingga, 2011).

Multivariate analysis is a method for rapid and cheap to identify goat breeds and has been widely used to study the breed characterization of goat in Indonesia (Batubara et al., 2011; Kurnianto et al., 2013), goat in Nigeria (Yakubu et al., 2010; Okpeku et al., 2011; Yakubu et al., 2011), goat in Burkina Faso (Traore et al., 2008), goat in Ghana (Birteeb et al., 2012), goat in Saudi Arabia (Aziz and Al-Hur, 2013). Skeletal characters including cranium form reveal the highest heritability of all the quantitative traits. Therefore, application of an appropriate statistical analysis to the skeletal measurement can used to identify a strain within an animal species and estimate closeness of relationships among different strains (Goto et al., 1991).

The purpose of this study was to identify the size and shape of cranium of three breeds of Central Java local goats (Kejobong, Kacang and Ettawa Grade). Besides, the purpose was to examine the effectiveness of multivariate analysis of cranial measurement, and to estimate genetic distance among three local breeds of goat in Central Java.

\section{MATERIALS AND METHODS}

This research was conducted in Purbalingga and Grobogan regencies, Central Java Province, Indonesia. Purposive sampling method was applied to determine the location on the basis of population density of the goat breeds. The materials studied were female goats and aged about 4 years old (determined on the basis based on the teeth eruption). The number of specimens for Kejobong, Kacang and Ettawa Grade goats were 30, 10 and 10, respectively. Sample was collected and measured from slaughter houses in Purbalingga and Grobogan respectively.

Twenty seven cranial measurements used in this study, was based on the definition of Ozcan et al. (2010) as shown in Figure 1 including the important measuring points. All measurements were taken with sliding or spreading calipers and were recorded to the nearest 0.1 millimeters.

\section{Statistical analysis}

The data were subjected to used for univariate and multivariate analysis using General Linear Model (GLM) procedure. CANDISC procedure (SAS, 2004) was used to perform a canonical discriminant analysis and to compute squared Mahalanobis distance. Squared Mahalanobis distance obtained then was administered to MEGA 5 to construct phylogeny through UPGMA (Unweighted Pair-Group Method with Arithmetic Mean) tree (Tamura et al., 2011). The between-breed squared Mahalanobis distance matrix was computed as Mahalanobis distance that is written as:

$$
D_{i j}^{2}=\left(X_{i}-X_{j}\right)^{\prime} \operatorname{Cov}^{-1}\left(X_{i}-X_{j}\right)
$$

Where:

$\mathrm{D}_{\mathrm{ij}}{ }^{2} \quad$ : distance between $\mathrm{i}^{\text {th }}$ breed and $\mathrm{j}^{\text {th }}$ breed.

$\mathrm{Cov}^{-1} \quad$ : the inverse of the covariance matrix of measured variable $\mathrm{X}$.

$X_{i}$ and $X_{j}$ : are the means of variable $X$ in $i^{\text {th }}$ breed and $\mathrm{j}^{\text {th }}$ breed, respectively.

PRINCOMP procedure (SAS, 2004) was performed to determine principal component analysis (PCA). DISCRIM procedure was performed to evaluate the misclassified of breed and Mahalanobis distance among breeds. 

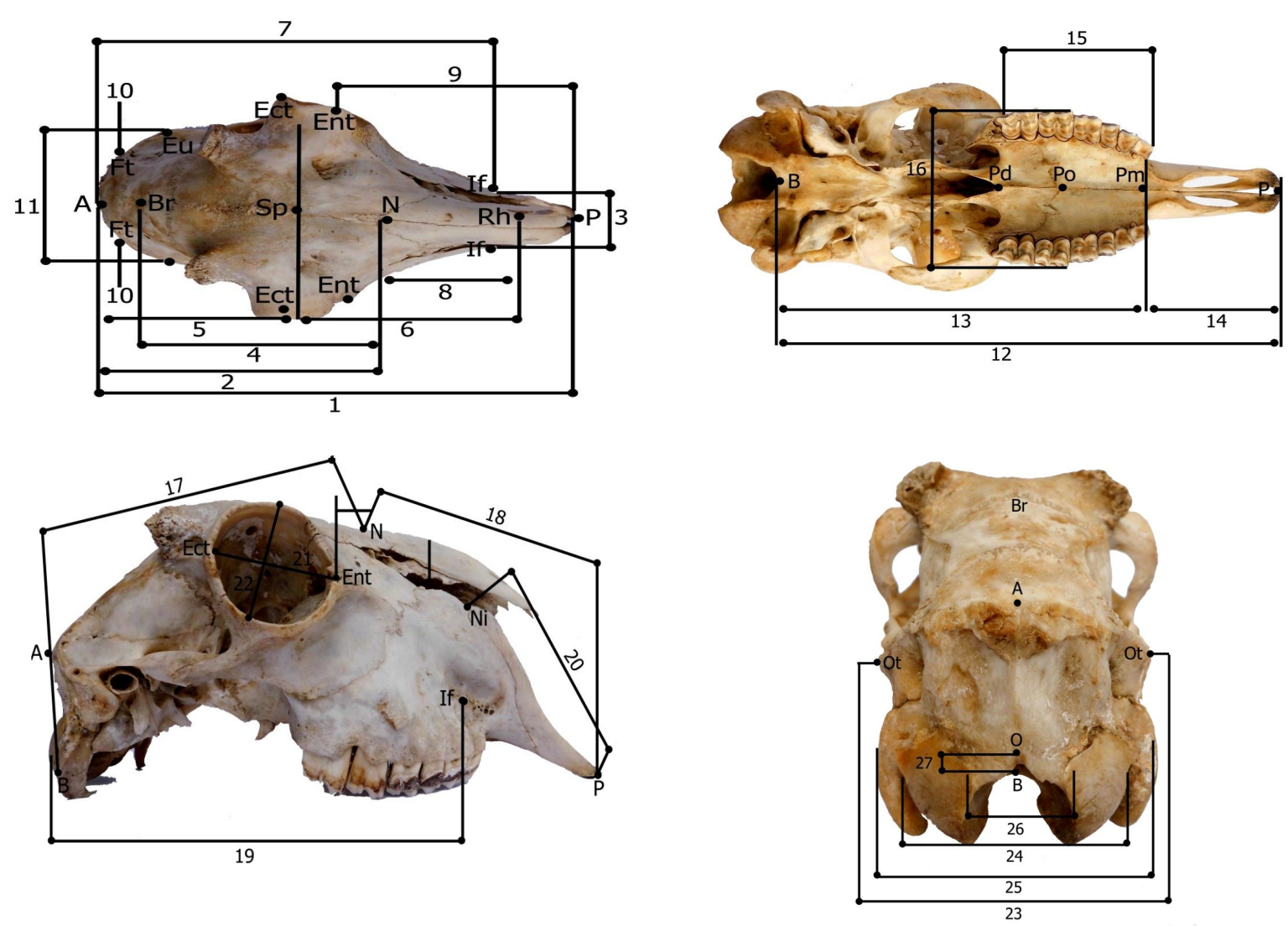

Figure 1. Measurements of the Cranium of the Kejobong, Kacang and Ettawa Grade Goats where:

1 : Profile length

2 : Median frontal length

3 : Greatest breadth across the premaxillae

4 : Frontal length

5 : Upper neurocranium length

6 : Facial length

7 : Akrokraniom-infraorbitale of one side

8 : Greatest length of nasals

9 : Short lateral facial length

10 : Least breadth of the parietal

11 : Greatest neurocranium breadth

12 : Basal length

13 : Short skull length

14 : Premolare-prosthion

15 : Length of the cheektooth row

\section{RESULTS AND DISCUSSION}

Cranium measurements of three breeds of goat are presented in Table 1. Based on the analysis for the result measurements of the cranium among goat breeds, there was differences
16 : Greatest palatal breadth

17 : Neurocranium length

18 : Viscerocranium length

19 : From the aboral border of one occipital condyle to the infraorbitale of the same side

20 : Lateral length of the premaxilla

21 : Greatest inner length of the orbit

22 : Greatest inner height of the orbit

23 : Greatest mastoid breadth

24 : Greatest breadth of the occipital condyles

25 : Greatest breadth of the bases of the paroccipital processes

26 : Greatest breadth of the foramen magnum

27 : Height of the foramen magnum

among three local goat breeds $(\mathrm{P}<0.05)$ for all variables cranium size, except on variables 3 (greatest breadth across the premaxillae), 14 (premolare-prosthion) and 16 (greatest palatal breadth). It shows that almost all variables were influenced by differences in cranial size goat 
Table 1. Cranium Measurements of Three Breeds of Goat

\begin{tabular}{|c|c|c|c|}
\hline \multirow{2}{*}{ Variable } & \multicolumn{3}{|c|}{ Breed } \\
\hline & Kejobong & Kacang & Ettawa Grade \\
\hline \multicolumn{4}{|c|}{ (1) } \\
\hline 1 & $22.78 \pm 1.13^{\mathrm{b}}$ & $22.73 \pm 0.79^{\mathrm{b}}$ & $24.07 \pm 0.69^{\mathrm{a}}$ \\
\hline 2 & $12.99 \pm 0.67^{\mathrm{ab}}$ & $12.60 \pm 0.87^{\mathrm{b}}$ & $13.17 \pm 0.49^{\mathrm{a}}$ \\
\hline 3 & $3.59 \pm 0.37^{\mathrm{a}}$ & $3.45 \pm 0.23^{\mathrm{a}}$ & $3.48 \pm 0.25^{\mathrm{a}}$ \\
\hline 4 & $10.44 \pm 0.75^{\mathrm{a}}$ & $9.78 \pm 0.81^{b}$ & $10.44 \pm 0.44^{\mathrm{a}}$ \\
\hline 5 & $10.13 \pm 0.82^{\mathrm{b}}$ & $10.17 \pm 1.41^{\mathrm{b}}$ & $11.22 \pm 0.61^{\mathrm{a}}$ \\
\hline 6 & $15.76 \pm 1.10^{\mathrm{a}}$ & $14.39 \pm 0.89^{\mathrm{b}}$ & $16.21 \pm 0.95^{\mathrm{a}}$ \\
\hline 7 & $15.99 \pm 0.88^{\mathrm{b}}$ & $15.84 \pm 0.51^{b}$ & $16.84 \pm 0.51^{\mathrm{a}}$ \\
\hline 8 & $11.77 \pm 0.95^{\mathrm{b}}$ & $11.54 \pm 0.86^{\mathrm{b}}$ & $13.50 \pm 1.06^{\mathrm{a}}$ \\
\hline 9 & $13.25 \pm 0.86^{\mathrm{b}}$ & $13.26 \pm 0.54^{\mathrm{b}}$ & $13.99 \pm 0.46^{\mathrm{a}}$ \\
\hline 10 & $3.07 \pm 0.27^{\mathrm{a}}$ & $2.83 \pm 0.31^{b}$ & $3.18 \pm 0.39^{\mathrm{a}}$ \\
\hline 11 & $5.30 \pm 0.31^{\mathrm{b}}$ & $5.05 \pm 0.68^{b}$ & $5.68 \pm 0.40^{\mathrm{a}}$ \\
\hline 12 & $19.88 \pm 1.33^{\mathrm{ab}}$ & $19.75 \pm 0.70^{b}$ & $20.73 \pm 0.74^{\mathrm{a}}$ \\
\hline 13 & $14.55 \pm 0.86^{\mathrm{b}}$ & $14.29 \pm 0.45^{\mathrm{b}}$ & $15.32 \pm 0.56^{\mathrm{a}}$ \\
\hline 14 & $5.34 \pm 0.36^{\mathrm{a}}$ & $5.36 \pm 0.27^{\mathrm{a}}$ & $5.58 \pm 0.40^{\mathrm{a}}$ \\
\hline 15 & $7.00 \pm 0.42^{\mathrm{ab}}$ & $6.82 \pm 0.19^{b}$ & $7.28 \pm 0.37^{\mathrm{a}}$ \\
\hline 16 & $6.42 \pm 0.47^{\mathrm{a}}$ & $6.43 \pm 0.35^{\mathrm{a}}$ & $6.43 \pm 0.37^{\mathrm{a}}$ \\
\hline 17 & $13.13 \pm 0.68^{\mathrm{a}}$ & $12.46 \pm 0.56^{\mathrm{b}}$ & $13.39 \pm 0.51^{\mathrm{a}}$ \\
\hline 18 & $13.63 \pm 1.08^{b}$ & $13.19 \pm 0.77^{b}$ & $15.16 \pm 0.83^{\mathrm{a}}$ \\
\hline 19 & $15.48 \pm 0.94^{\mathrm{b}}$ & $15.41 \pm 0.57^{b}$ & $16.38 \pm 0.56^{\mathrm{a}}$ \\
\hline 20 & $9.28 \pm 1.00^{\mathrm{b}}$ & $9.85 \pm 0.92^{b}$ & $11.11 \pm 0.54^{\mathrm{a}}$ \\
\hline 21 & $3.67 \pm 0.27^{\mathrm{b}}$ & $3.77 \pm 0.15^{b}$ & $3.98 \pm 0.13^{\mathrm{a}}$ \\
\hline 22 & $3.41 \pm 0.22^{\mathrm{ab}}$ & $3.31 \pm 0.19^{b}$ & $3.50 \pm 0.18^{\mathrm{a}}$ \\
\hline 23 & $7.74 \pm 0.45^{\mathrm{b}}$ & $7.76 \pm 0.25^{\mathrm{b}}$ & $8.47 \pm 0.33^{\mathrm{a}}$ \\
\hline 24 & $5.34 \pm 0.32^{\mathrm{a}}$ & $4.98 \pm 0.19^{b}$ & $5.53 \pm 0.26^{\mathrm{a}}$ \\
\hline 25 & $6.95 \pm 0.41^{\mathrm{b}}$ & $6.86 \pm 0.26^{\mathrm{b}}$ & $7.61 \pm 0.34^{\mathrm{a}}$ \\
\hline 26 & $2.09 \pm 0.33^{\mathrm{a}}$ & $1.82 \pm 0.17^{b}$ & $2.01 \pm 0.30^{\mathrm{ab}}$ \\
\hline 27 & $2.27 \pm 0.21^{\mathrm{a}}$ & $2.09 \pm 0.17^{\mathrm{b}}$ & $2.26 \pm 0.23^{\mathrm{a}}$ \\
\hline
\end{tabular}

Different superscript at the same row indicate differ significantly $(\mathrm{P}<0.05)$; Variables see to Figure 1.

breeds. Cranium is part of the body that is genetically derived from a particular breed, so that every breed has a cranial measures different compared to other breeds (Saparto, 2006).

Most of variable size cranium of Ettawa Grade were the greatest size, it were followed by
Kejobong and Kacang goats. According to Pamungkas et al. (2009), Ettawa Grade goat is the result of a cross between a Ettawa goat (from India) with Kacang goat, which looks similar performance but smaller than Ettawa goat.

The principal component analysis has often 
Table 2. Eigenvalue and its Contribution in Each Principal Component

\begin{tabular}{cccc}
\hline $\begin{array}{c}\text { Principal Component } \\
\text { (PC) }\end{array}$ & Eigenvalue & Contribution Ratio & $\begin{array}{c}\text { Cumulative Contribution } \\
\text { Ratio (\%) }\end{array}$ \\
\hline I & 8.98990275 & 0.5959 & 59.59 \\
II & 1.51030885 & 0.1001 & 69.60 \\
\hline
\end{tabular}

Table 3. Eigenvector of Each Principal Component

\begin{tabular}{ccc}
\hline Variables & PC-I & PC-II \\
\hline 1 & 0.308451 & 0.081872 \\
2 & 0.132184 & 0.395145 \\
3 & 0.007479 & 0.031295 \\
4 & 0.097083 & 0.413347 \\
5 & 0.191190 & 0.293483 \\
6 & 0.313542 & -0.088548 \\
7 & 0.233882 & 0.144768 \\
8 & 0.331978 & -0.472760 \\
9 & 0.231412 & -0.017523 \\
10 & 0.022805 & 0.017856 \\
11 & 0.070983 & -0.051922 \\
12 & 0.338330 & 0.127886 \\
13 & 0.245176 & 0.088636 \\
14 & 0.077418 & 0.023495 \\
15 & 0.057923 & 0.053863 \\
16 & 0.078748 & 0.050290 \\
17 & 0.154087 & 0.245713 \\
18 & 0.311582 & -0.462315 \\
19 & 0.258493 & 0.080384 \\
20 & 0.321781 & -0.021092 \\
21 & 0.053546 & 0.020524 \\
22 & 0.042859 & 0.017730 \\
23 & 0.119950 & 0.030810 \\
24 & 0.059083 & -0.035525 \\
25 & 0.120225 & 0.000902 \\
26 & 0.016795 & -0.093266 \\
27 & 0.019675 & 0.026679 \\
\hline & \\
\hline
\end{tabular}

Variables see to Figure 1.

been applied to discriminate animal population (Blackith and Reyment, 1971) and the efficiency of this method for cattle has been presented in previous report (Hayashi et al., 1981; Nishida et al., 1983; Saparto, 2006). Each of principal component used in this study was extracted from the covariance matrix of 27 cranial measurements. Table 2 shows the eigenvalue and its contribution in each principal component (PC). Result indicated that $69.60 \%$ of cumulative contribution ratio from the PC-I to the PC-II. This means that the first two PCs extracted accounted for more than $69 \%$ of morphometrical variation information. Saparto (2006) who used several variables cranium in Indonesian native cattle showed the contribution of PC-I amounting to $51.97 \%$ and PC-II was $67.82 \%$. Hayashi et al. (1982) reported on the several variables of native cattle breed in Asia showing the contribution of PC-I amounting to $65.3 \%$ and $9.3 \%$ at PC-II.

Table 3 presents eigenvectors of PC-I and PC-II. In PC-I, all eigenvectors had positive values, while in PC-II, eight eigenvectors representing length of cranium showed negative values. According to Hayashi et al. (1982), in morphometrical application of the principal component analysis, the first component was acceptable as size, and the second one as a shape. The scattering diagram of 3 breeds of goats constructed by PC-I and PC-II is presented in Figure 2.

Figure 2 presents plotting membership of breed based on the cranium measurements. Ettawa Grade showed the largest size proved by positive value of PC-I and negative value of PCII, followed by Kejobong breed. Kejobong goat breed showed the negative value of PC-I and positive value of PC-II, showing that Kejobong goats were small cranium size with large cranium shape. Different thing was found in Kacang goats, in which the cranium size and shape were relatively small due to the negative value of PC-I and negative value of PC-II. Kacang breed showed the smaller size compared to Ettawa 
Grade and Kejobong breed.

According to Kurnianto et al. (2013), historically, Kacang goat is the indigenous breed of Indonesia, included in Central Java. Ettawa Grade goat is a breed originating from the grading up of goat breeds introduced from India (Ettawa or Benggala) and local breed from hundreds years ago. Kejobong goat is a new breed that is the result of crossbreeding between Ettawa and Kacang breeds. Kejobong goats initially were only found in Purbalingga Regency, Central Java, especially in Kejobong District.

In general, the goats among several breeds suspected of having genetic relationship according to body measurements. According to Suparyanto et al. (1999), phenotypic similarity in body size of various breeds is a reflection of the magnitude of a mixed group of breeds that occurred either by the mutation breeder modified or naturally occurring.

Discriminant function analysis to determine the percentage of erroneous level of grouping into their own breeds on the basis of cranium measurements is presented in Table 4. Using Canonical Discriminant analysis for classifying three types local goat breeds resulted in the high accuration as indicated by $0 \%$ of misclassification. This suggests that there was a high uniformity due to the homogeneity of the breed. The results of this investigation suggested that cranium analysis is applicable to discriminate of three types goat breed.

In the discriminant analysis, the Mahalanobis distance based on the 27 measurement were calculated among three breeds. Because the cranium size and shape are highly heritable traits,

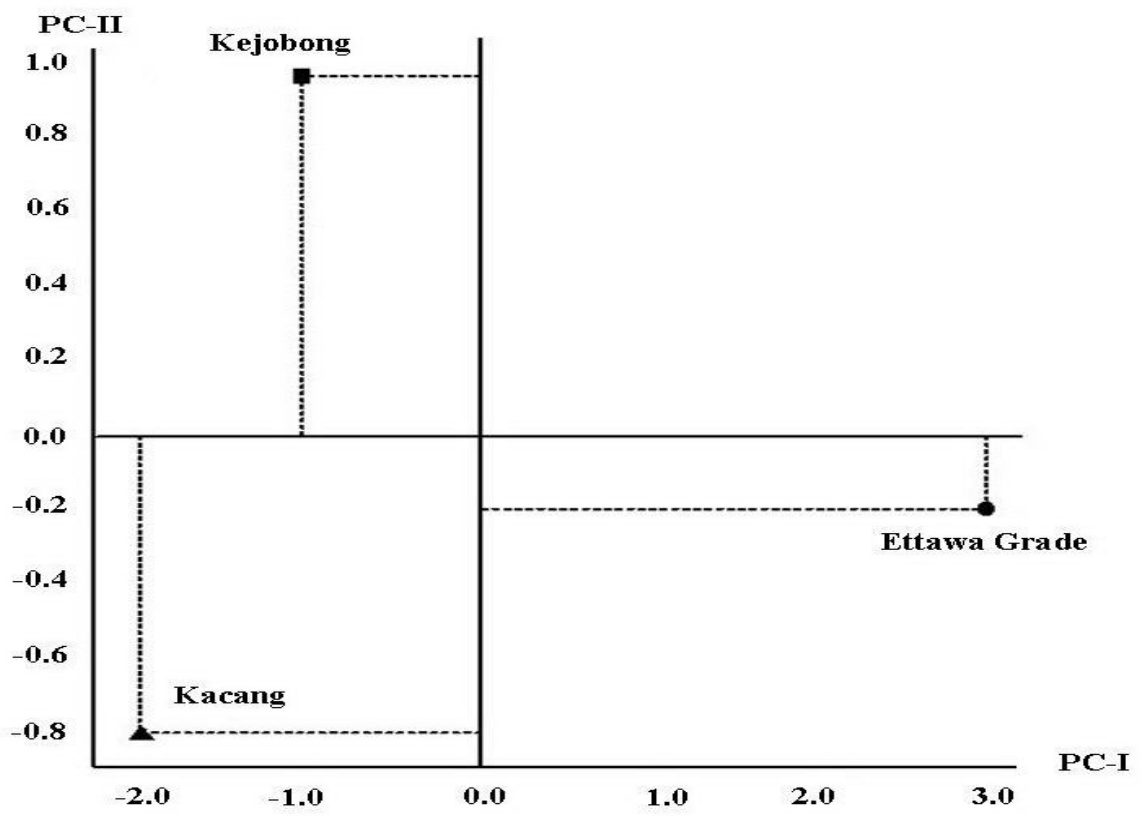

Figure 2. Plot of Membership on Average Cranium Measurements of Three Breed of Local Goat Breeds

Table 4. Results of Classification Analysis by Means of Discriminant Analysis

\begin{tabular}{lcccc}
\hline \multicolumn{1}{c}{ Breed } & Kacang Goat & Kejobong Goat & Ettawa Grade Goat & Total \\
\hline Kacang Goat & $10(100)$ & $0(0)$ & $0(0)$ & $10(100)$ \\
Kejobong Goat & $0(0)$ & $30(100)$ & $0(0)$ & $30(100)$ \\
Ettawa Grade Goat & $0(0)$ & $0(0)$ & $10(100)$ & $10(100)$ \\
Total & $10(20)$ & $30(60)$ & $10(20)$ & $50(100)$ \\
\hline
\end{tabular}

Number in the bracket indicates $\%$ of classification rightness 
Table 5. Mahalanobis Distance Among the Three Breeds of Local Goat Based the Cranial Measurement

\begin{tabular}{lccc}
\hline \multicolumn{1}{c}{ Breed } & Kacang Goat & Kejobong Goat & Ettawa Grade Goat \\
\hline Kacang Goat & 0 & 39.73 & 27.30 \\
Kejobong Goat & 39.73 & 0 & 55.88 \\
Ettawa Grade Goat & 27.30 & 55.88 & 0 \\
\hline
\end{tabular}

the distance may reflect the genetic distance between breeds (Saparto, 2006). Table 5 shows the Mahalanobis distance among three breeds of local goat. Kacang goat showed the nearest distance to Ettawa Grade. Kejobong goat had a closer distance with Kacang goat, compared to Ettawa Grade goat.

\section{CONCLUSION}

Three breeds of local goats in Central Java could be categorized into two major groups on the basis of cranium measurements, where the first group was of Kacang and Ettawa Grade goats, and the second group was Kejobong. Kejobong goat had a closer relationship with Kacang goat than to Ettawa Grade goat.

\section{ACKNOWLEDGMENTS}

This research was partly financed by Riset Unggulan Daerah - Balitbang Provinsi Jawa Tengah 2013. The authors would like to thank Head of Animal Husbandry Service at Purbalingga and Grobogan Regencies for allowing the research and their staffs for gathering data. The authors also thank research team of Kejobong goat for good cooperation.

\section{REFERENCES}

Aziz, M. M. A. and F. S. Al Hur. 2013. Differentiation between three Saudi goat types using size-free canonical discriminant analysis. Emir. J. Food Agric. 25(9):723-735

Batubara, A., R. R. Noor, A. Farajallah, B. Tiesnamurti, and M. Doloksaribu. 2011. Morphometric and phylogenic analysis of six population Indonesian local goats. Media Peternakan. 34(3) :165-174.

Birteeb P. T., S. O. Peters, A. Yakubu, M. A. Adeleke, and M. O. Ozoje. 2012. Multivariate characterization of the phenotypic traits of Djallonke and Sahel sheep in Northern Ghana. Trop. Anim. Health. Prod. 12:23-27

Blackith, R. E., and R. A. Reyment. 1971. Multivariate Morphometrics. Academic Press, New York.

Dinas Peternakan dan Perikanan Kabupaten Purbalingga. 2011. Statistik Peternakan. Dinas Peternakan dan Perikanan Kabupaten Purbalingga. Purbalingga.

Direktorat Jenderal Peternakan dan Kesehatan Hewan. 2013. Statistik Peternakan 2013. Direktorat Jenderal Peternakan dan Kesehatan Hewan Departemen Pertanian RI. Jakarta.

Goto, N., K. Fukuta, T. Serikawa and J. Yamada. 1991. Strain identification of inbred rats using mandible measurements. J. Mammal. Soc. Japan. 15(2):73-82

Hayashi, Y., J. Otsuka, T. Nishida and H. Martojo. 1982. Multivariate craniometrics of wild banteng, Bos banteng and five types of native cattle in Eastern Asia. The Origin and Phylogeny of Indonesian Native Livestock. Part III. The Research Group of Overseases Scientific Survey, Page: 19-30

Hayashi, Y., T. Nishida, K. Mochizuki and J. Otsuka. 1981. Measurements of the skull of native cattle and Banteng in Indonesia. Jpn. J. Vet. Sci. 43: 901-907.

Kurnianto, E., S. Sutopo, E. Purbowati, E. T. Setiatin, D. Samsudewa and T. Permatasari. 2013. Multivariate analysis of morphological traits of local goats in central Java, Indonesia. Iranian J. Appl. Anim. Sci. 3(2): 361-367.

Nishida, T., Y. Hayashi, C. S. Lee, and Y. J. Cho. 1983. Measurement of the skull of native cattle Korea. Jpn. J. Vet. Sci. 45: 537-541.

Okpeku M., A. Yakubu, S.O. Peters, M.O., C.O.N. Ikeobi, O.A. Adebambo and I.G. Imumorin. 2011. Application of multivariate principal component analysis to morphological 
characterization of indigenous goats I Southern Nigeria. Act. Agric. Slovenica. 98:101-109

Ozcan, S., G. Aksoy, I. Kurtul, K. Aslan and Z. Ozudogru. 2010. A comparative morphometric study on the skull of the Tuj and Morkaraman sheep. Kafkas Univ. Vet. Fak. Derg. 16 (1): 111-114

Pamungkas, F. A., A. Batubara, M. Doloksaribu and E. Sihite. 2009. Petunjuk Teknis Potensi Beberapa Plasma Nutfah Kambing Lokal Indonesia. Pusat Penelitian dan Pengembangan Peternakan, Deli Serdang.

Purbowati, E. and E. Rianto. 2010. Study of physical characteristics and performance of Kejobong goats in Kejobong, Purbalingga, Central Java, Indonesia. Proceedings of the $14^{\text {th }}$ Animal Science Congress of the AAAP. 23-27 August 2010. Pingtung-Taiwan, ROC. 3:2062-2065.

Saparto. 2006. Breed identification of four types Indonesian native cattle. Anim. Prod. 8(3):174-181.

SAS Institute. 2004. SAS ${ }^{\circledR} / \mathrm{STAT}$ Software, Release 9.11. SAS Institute, Inc., Cary, North Carolina.

Sodiq, A. and B. Haryanto. 2007. Non-genetic factors influence on doe productivity performance of local Kejobong goat under village production system. Anim. Prod. 9(3) : $123-128$.

Sodiq, A. and M.Y. Sumaryadi. 2002. Productive performance of Kacang and Peranakan Etawah goat in Indonesia. Anim. Prod. 4:5259.

Suparyanto A., T. Purwadaria and Subandriyo. 1999. Pendugaan jarak genetik dan faktor peubah pembeda bangsa dan kelompok domba di Indonesia melalui pendekatan analisis morfologi. J. Ilmu Tern. Vet. 4:8087.

Tamura K., D. Peterson, N. Peterson, G. Stecher, M. Nei and S. Kumar. 2011. MEGA 5: Molecular evolutionary genetics analysis using maximum likelihood, evolutionary distance, and maximum Parsimony methods. Mol. Biol. Evol. 28:2731-2739.

Traore, A., H. H. Tamboura, A. Kabore, L. J. Royo, I. Fernandez, I. Alvarez, M. Sangare, D. Bouchel, J. P. Poivey, D. Francois, L. Sawadogo and F. Goyache. 2008. Multivariate analyses on morphological traits of goats in Burkina Faso. Arch. Tierz. Dummerstorf. 51:588-600.

Yakubu, A., A. E. Salako, I. G. Imumorin, A. O. Ige and M. O. Akinyemi. 2010. Discriminant analysis of morphometric differentiation in the West African Dwarf and Red Sokoto goats. S. Afr J. Anim. Sci. 40(4):381-387.

Yakubu, A., A. E. Salako and I. G Imumorin. 2011. Comparative multivariate analysis of biometric traits of West African Dwarf and Red Sokoto goats. Trop. Anim. Health. Prod. 43:561-566. 